\title{
High resolution modelling of aerosol dispersion regimes during the CAPITOUL field experiment: from regional to local scale interactions
}

\author{
B. Aouizerats ${ }^{1}$, P. Tulet ${ }^{1,2}$, G. Pigeon ${ }^{1}$, V. Masson ${ }^{1}$, and L. Gomes ${ }^{1}$ \\ ${ }^{1}$ CNRM-GAME, URA1357, 42 av G. Coriolis, 31057 Toulouse, France \\ ${ }^{2}$ LACy, Université de La Réunion, 15 av René Cassin, 97715 Saint-Denis, France
}

Received: 8 October 2010 - Published in Atmos. Chem. Phys. Discuss.: 3 December 2010

Revised: 18 July 2011 - Accepted: 24 July 2011 - Published: 1 August 2011

\begin{abstract}
High resolution simulation of complex aerosol particle evolution and gaseous chemistry over an atmospheric urban area is of great interest for understanding air quality and processes. In this context, the CAPITOUL (Canopy and Aerosol Particle Interactions in the Toulouse Urban Layer) field experiment aims at a better understanding of the interactions between the urban dynamics and the aerosol plumes. During a two-day Intensive Observational Period, a numerical model experiment was set up to reproduce the spatial distribution of specific particle pollutants, from the regional scales and the interactions between different cities, to the local scales with specific turbulent structures. Observations show that local dynamics depends on the day-regime, and may lead to different mesoscale dynamical structures. This study focuses on reproducing these fine scale dynamical structures, and investigate the impact on the aerosol plume dispersion. The 500-m resolution simulation manages to reproduce convective rolls at local scale, which concentrate most of the aerosol particles and can locally affect the pollutant dispersion and air quality.
\end{abstract}

\section{Introduction}

Since 2007, more than half of Earth's population lives in urban areas (Brown, 2001). Moreover, the newly dominant urban population is growing three times faster than rural population. Therefore, urban issues are more than ever relevant issues. One of the deficiencies in urban standard of living is its vulnerability to meteorological events, including pol-

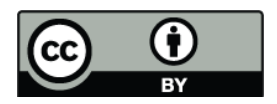

Correspondence to: $\mathrm{B}$. Aouizerats (benjamin.aouizerats@cnrm.meteo.fr) lution events which result from the high population density Such high pollution event become more frequent, and national regulations have been introduced in order to counter these effects.

Air quality models are used to forecast these pollution events, and are usually linked with regional models or chemical transport models. For pollution events forecasting, meteorology is one of the main sources of uncertainties (Baklanov et al., 2007). Indeed, many meteorological processes can greatly affect the concentration of pollutants, and may increase the concentration to an alert level. Aerosol particles are now considered as a potential risk for health, and pollution alert criterias now take them into account. More and more studies investigate the particle pollution events (Cubison et al., 2006; Aiken et al., 2010). Most air quality models, such as CMAQ (Smith and Mueller, 2010), CHIMERE (Bessagnet et al., 2009), MOCAGE (Lefevre et al., 1994) or CAC (Gross and Sorensen, 2007) simulate the emissions and transport of particles. However, the dynamical variables at each time steps are usually interpolated between the dynamical fields from the coupled meteorological analyses. It may be the source of errors, especially when there are high spatial or temporal gradient between the two coupled dynamical fields used for interpolation. One of the specific aspects of this modelling exercise is to focus on the importance of the horizontal resolution in order to reproduce local scale processes such as convective roll structures driving the pollutant distribution. Such simulations where the chemistry and aerosol equilibrium are solved at small scale are numerically expensive but may be the only way to reproduce coherent dynamical structures that are found in observation.

The CAPITOUL (Canopy and Aerosol Particle Interactions in the Toulouse Urban Layer) field experiment took place during one year in Toulouse, France, to study specific

Published by Copernicus Publications on behalf of the European Geosciences Union. 

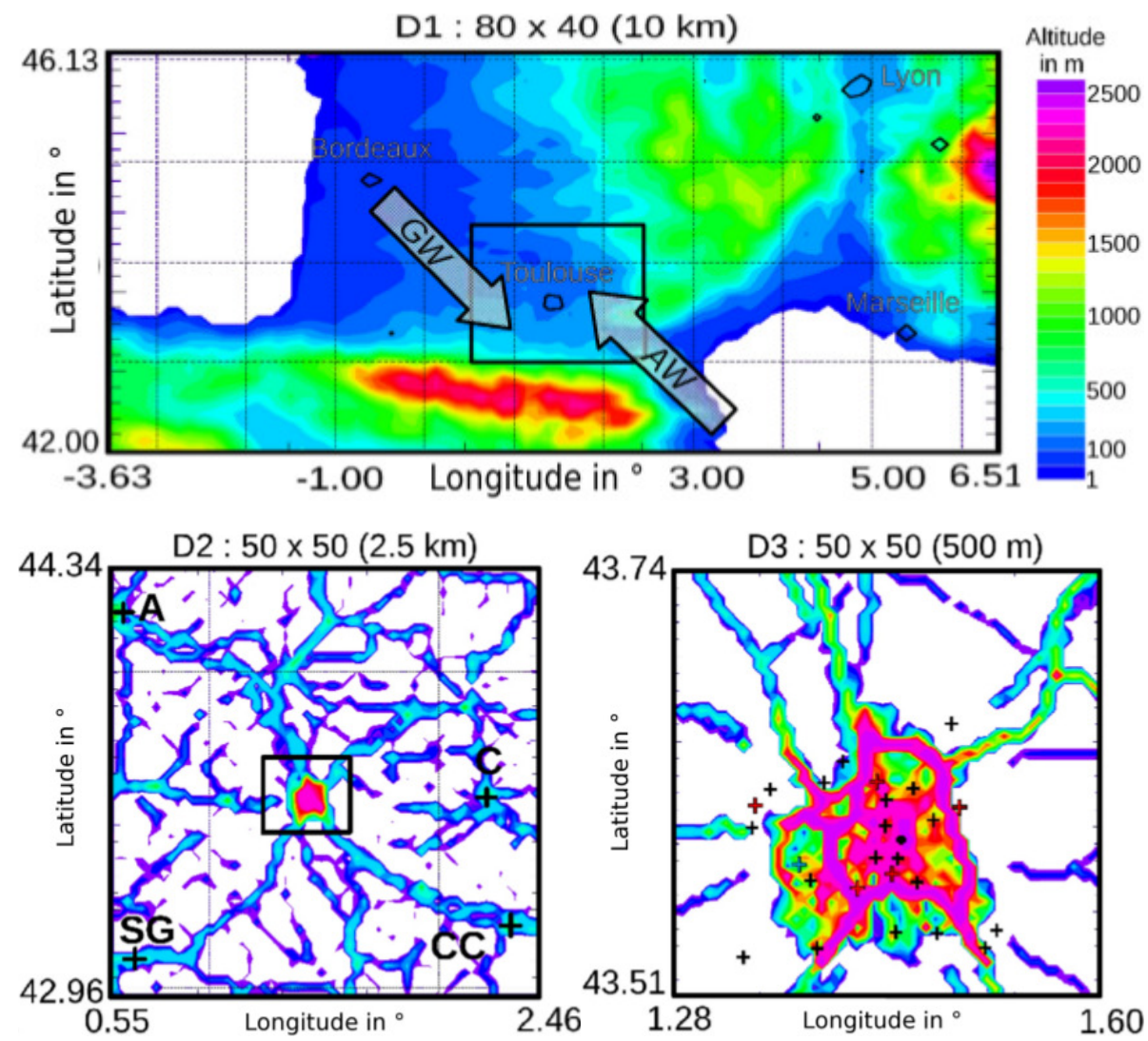

Fig. 1. The three nested domains color-coded for (a) elevation above sea level in meter, (b) and (c) and black carbon emissions in ppb $\mathrm{m} \mathrm{s}^{-1}$ on 3 July 10:00 UTC. In (a) the arrows symbolise the two dominant wind regimes AW for the Autan wind and GW for the general wind. The black crosses over the 2nd domain (b) mark the main regional cities: A for Agen, SG for Saint-Gaudens, CC for Carcassonne, and C for Castres. The crosses over the 3rd (c) domain denote the observational network; black and red crosses show the light meteorological stations and the gaseous chemistry stations, respectively.

urban processes (Masson et al., 2008). During the year of measurements, several Intensive Observation Period (IOP) were sampled for different meteorological conditions from winter to summer. This study focuses on a two-day IOP which occurred on 3 and 4 July 2004 to study the pollution events and the aging of aerosols during sunny conditions. In this context, the measurements acquired during this campaign were expoited leading to a modelling experiment in order to reproduce the dynamical, chemical and aerosol fields observed during this IOP. The model results at fine scale were used to investigate the influence of local dynamics on aerosol plume dispersion, and the importance of local turbulent structures on aerosol spatial concentrations.

This article will first describe the methodology of the study, which includes the description of the CAPITOUL campaign and the configuration of the simulation. Then, the two-day IOP will be analysed from the regional scale to the local urban scale. Finally, a focus on the roll structure reproduced by the simulation will be presented.

\section{Methodology}

\subsection{The CAPITOUL field experiment}

The CAPITOUL campaign took place from February 2004 to February 2005 in the city of Toulouse, located in southwest France (Masson et al., 2008). Figure 1a shows the location of Toulouse and the elevation levels highlighting the wind corridor from northwest to southeast. The two arrows represent the prevailing winds which exist over the Toulouse area: the Autan wind (AW) blows from the Mediterranean sea to the northwest, while the general synoptic wind (GW) blows from the Atlantic Ocean to the southeast. The main regional cities with a potential pollution interaction are shown with black contours: Marseille (M) with 1000000 inhabitants, Lyon (L) with 1200000 inhabitants, Bordeaux (B) with 800000 inhabitants and Toulouse (T) with 860000 inhabitants.

This campaign aimed at studying the urban climate, including the energetic exchanges between the surface and the atmosphere, the dynamics of the boundary layer over the city, 
and its interactions with aerosol chemistry. In this context the aging of aerosol particles and the interactions between the urban dynamics and the dispersion of pollutant particles are especially relevant during summer, when the photochemistry is high and encourages the formation of secondary aerosols. The IOP chosen for this study occurred during Saturday and Sunday, 3-4 July 2004, which fell on a holiday week-end with high nocturnal traffic compared with a typical weekly day. The choice of this IOP allows us wihtin an anticylonic situation to study the two main wind regimes which are representative of the dynamical situation in the Toulouse area. During this period, the observational network included surface stations (meteorology, energy balance, chemistry), profilers and balloons. Moreover, a downtown-site located in Toulouse, described by Gomes et al. (2008), was equipped for in-situ aerosol measurements.

\subsection{Model configuration}

To perform this numerical study, the research atmospheric model Meso-NH was used. Meso-NH (Lafore et al., 1998) is a non-hydrostatic and anelastic atmospheric model jointly developed by CNRM-GAME (MeteoFrance/Centre National de Recherche Scientifique) and Laboratoire d'Aérologie (Université Paul Sabatier/Centre National de Recherche Scientifique). The turbulence scheme is one dimensional along the vertical axis (Bougeault and Lacarrere, 1989). The surface computations include four main surface schemes: Town Energy Balance (TEB, Masson (2000)) for managing the urban areas, ISBA for the natural and agricultural covers (Noilhan and Planton, 1989), FLAKES for the lakes (Salgado and Moigne, 2010), and a scheme for sea-surface coverage (Fairall et al., 2003). The Town Energy Budget (TEB) scheme is built following the canyon approach, generalised in order to represent larger horizontal scales. The physics treated by the scheme is relatively complete, including different surface properties for roads, walls and roofs, and considering the day-time dependant sun zenithal angle and building heights. Due to the complex shape of the city surface, the urban energy budget is split into different parts. Three surface energy budgets are therefore considered: one for the roofs, one for the roads, and one for the walls. Orientation effects are averaged for roads and walls. The input data required by the TEB scheme are meteorological data (radiation from the sun (direct and diffuse), longwave radiation from the atmosphere, air temperature, humidity, wind, pressure, precipitations) and urban parameters describing the city for each grid mesh (mean fraction of building, mean fraction of roads, height of building, fraction of wall surface, albedo, emissivity, materials, insulation, heat capacity and thermal conductivity, thickness of walls and roofs). In addition to the meteorological variables, Meso-NH computes the gaseous chemistry evolution and solves the aerosol equilibrium at each time step and on each grid point (Tulet et al., 2003). The chemical reaction mod- ule employs a 82 species: ReLACS2 (Reduced Lumped Atmospheric Chemical Scheme 2) scheme (Tulet et al., 2005) based on the CACM (Caltech Atmospheric Chemistry Mechanism) scheme developed by Griffin et al. (2002).

The aerosol particle module, ORILAM-SOA (Organic Inorganic Lognormal Aerosol Model including Secondary Organic Aerosol) (Tulet et al., 2005, 2006) drives the aerosol dynamical processes (coagulation, sedimentation and deposition) as well as the thermodynamical equilibrium between gases and particles along the MPMPO (Model to Predict the Multiphase Partitioning of Organics) scheme (Griffin et al., 2002) for organic species and the scheme EQSAM (EQuilibrium Simplified Aerosol Module) (Metzger et al., 2002) for inorganic species in order to consider the condensation and nucleation processes. In the solving of aerosol condensation process, the assumption of not considering the molecular diffusion is done, considering the chemical equilibrium. The results of the use of EQSAM in a meso-scale model have been estimated (Tulet et al., 2006) and show similar results as the ISORROPIA module, with better computation times.

The aerosol species considered are:

- black carbon $(\mathrm{BC})$ and primary organic carbon $\left(\mathrm{OC}_{\mathrm{p}}\right)$ for the primary species

$-\mathrm{NO}_{3}^{-}, \mathrm{SO}_{4}^{2-}, \mathrm{NH}_{4}^{+}$for the inorganic ions

- 10 classes of secondary organic aerosol $\left(\mathrm{SOA}_{1, \ldots, 10}\right)$ from Griffin et al. (2002)

- water $\left(\mathrm{H}_{2} \mathrm{O}\right)$

The configuration used for the simulations is made of three nested domains, configured with a two-way interaction gridnesting, and represented in Fig. 1. The black squares on the first and second domain represent the second and third domain location, respectively. The first domain covers $800 \mathrm{~km}$ by $400 \mathrm{~km}$ with a $10 \mathrm{~km}$ resolution. The second domain centered on the city of Toulouse represents a 125 by $125 \mathrm{~km}^{2}$ square with a $2.5 \mathrm{~km}$ resolution. The third domain has a $500 \mathrm{~m}$ resolution and covers a $25 \times 25 \mathrm{~km}^{2}$ area centered on downtown Toulouse. The vertical axis has a 62-level nonlinear resolution, from $10 \mathrm{~m}$ above ground level (a.g.l.) to $1 \mathrm{~km}$ above $10 \mathrm{~km}$. The time step values are for the first, second and third domain 10,5 and $2.5 \mathrm{~s}$ respectively. The chemical solving uses 4 sub time step. To initialise the 2-day simulation, a 2-day spin-up is performed. During this 2-day spin-up, the first day is performed only with the first domain and the second day with the first and the second domains.

The regional forcing and initialisation are driven by ARPEGE re-analysis for the dynamics and MOCAGE for the gaseous initialisation. For particles, the background aerosols have been set up by deriving the $\mathrm{CO}$ concentration with a ratio obtained from Cachier et al. (2005) and which is similar to observations during the CAPITOUL campaign. This initialisation of the background aerosols within the atmosphere was done for primary particles $\left(\mathrm{OC}_{\mathrm{p}}\right.$ and $\left.\mathrm{BC}\right)$ in order to begin the 
two-day spin-up step with a non-empty particle atmosphere. The size distribution parameters used for the initialisation of the background particles are the same than used for the particles emission. Two lognormal modes are considered with median radius values of $36 \mathrm{~nm}$ and $385 \mathrm{~nm}$ and standard deviation values of 1.86 and 1.26 respectively. This values were deduced from the observations selected during the CAPITOUL campaign and representatives of the freshly emitted particles values (i.e. at night with a low boundary layer, and during a low-wind regime after an air-clean episode). The secondary particles are assumed to be produced during the spin-up step. The $\mathrm{CO}$ concentration in the atmosphere is initialised by the MOCAGE analyse fields corresponding to that period.

\subsection{Emission inventory}

In order to have a correct representation of the gas-phase chemistry and the aerosol particle concentrations, an emission inventory of particles and gases has been made.

For that purpose, road locations, traffic information during the IOP, and calculations from COPERT-4 software (Ntziachristos et al., 2009) are merged to form a 500-m resolution emission inventory over the third domain nested within a $2.5-\mathrm{km}, 10 \mathrm{~km}$ resolution emission inventory over the second and first domain respectively. This horizontal resolution is needed to be consistent with the horizontal resolution of the model. The COPERT-4 software is used for the computation of the averaged emissions for the major gases and particles over a year with the statistical data of French road traffic as an input. Then the emissions are scaled for one vehicle. Finally the traffic counts collected during the 2-day IOP are applied to the previous computation, in order to obtain an hourly emission database of $\mathrm{CO}, \mathrm{CO}_{2}, \mathrm{NO}_{\mathrm{x}}, \mathrm{SO}_{2}, \mathrm{BC}$ and $\mathrm{OC}_{\mathrm{p}}$. The VOC (Volatile Organic Compounds) emissions are deduced by applying a coefficient from Matsui et al. (2009) to $\mathrm{NO}_{\mathrm{x}}$ emissions. Assuming that the main $\mathrm{NH}_{3}$ emissions around Toulouse are not mainly from traffic emissions but due to agricultural activities, $\mathrm{NH}_{3}$ is emitted according to the GEMS inventory (Visschedijk et al., 2007) with an horizontal resolution of $\frac{1}{8}$ degree by $\frac{1}{16}$ degree. For the other emitted species, the assumption of considering only road transport emission was made. The reasons are that firstly there are almost negligible domestic combustion in summer, and secondly the region of Toulouse is relatively clean of any major industrial sources. The atmospheric concentrations being initialised by the MOCAGE fields, it appears reasonable to neglict the other industrial sources over France as their emissions reaching Toulouse are most likely low during those two days.

As an example, Fig. 1 shows the emissions of black carbon from this inventory over the second and third domain at 10:00 UTC the 3 July.

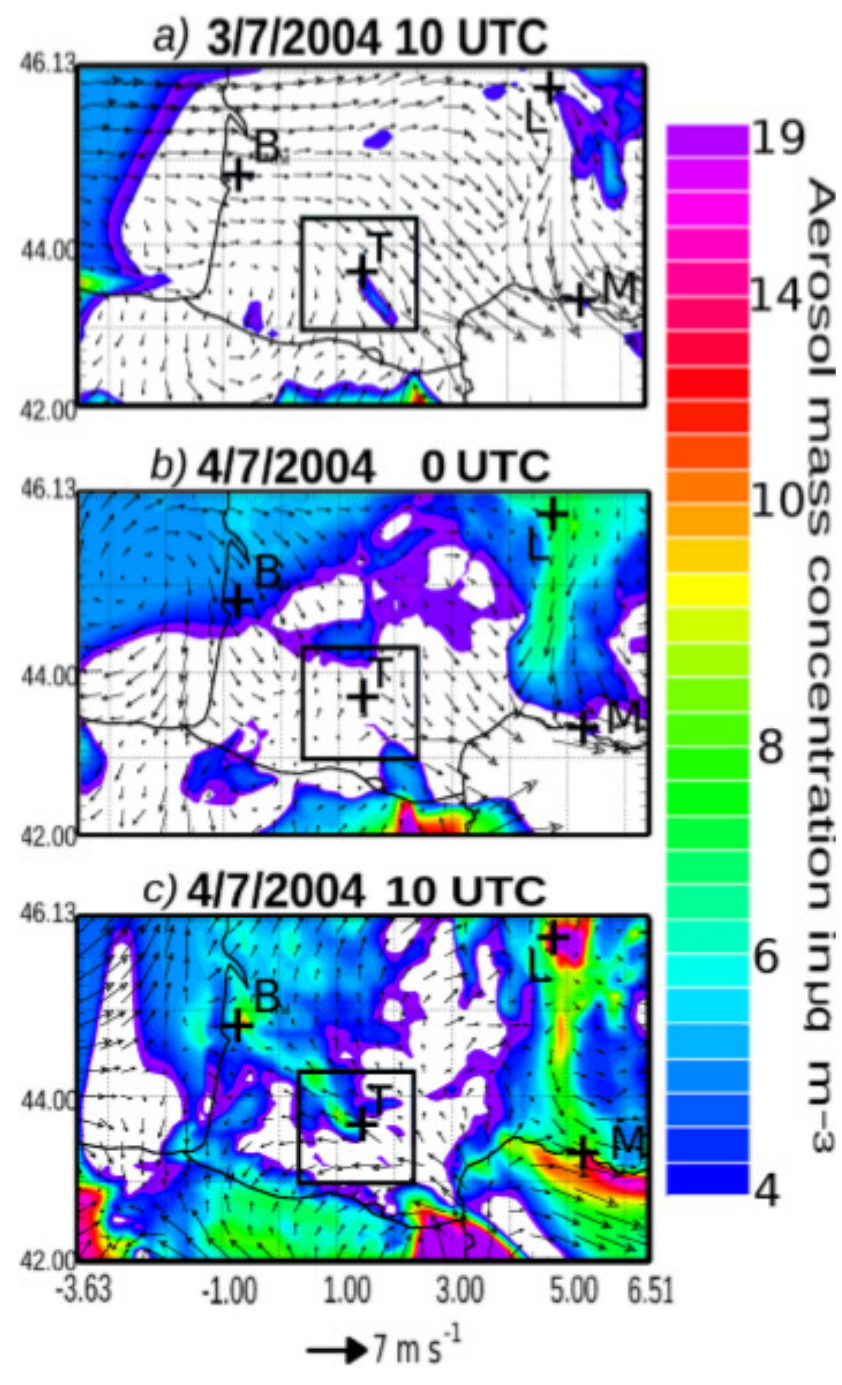

Fig. 2. Aerosol mass concentrations in $\mu \mathrm{g} \mathrm{m}^{-3}$ (color scale) over the 1st domain (a) on 3 July 10:00 UTC, (b) on 4 July 00:00 UTC, (c) on 4 July 10:00 UTC with the wind vectors at the ground level (black arrows). The main cities are drawn in black crosses: B for Bordeaux, T for Toulouse, L for Lyon and M for Marseille.

\section{Description of the IOP and model results}

\subsection{Description of the situation}

The situation observed and modeled during this two-day IOP has been analysed both at a meso-scale and at sub-regional scale.

\subsubsection{Meso scale pollution}

Figure 2 shows the aerosol mass concentrations above the surface over the first domain with a horizontal resolution of $10 \mathrm{~km}$ at three representative given moments: 3 July at 10:00 UTC, 4 July at 00:00 UTC and 4 July at 10:00 UTC. Figure 2 a shows that on 3 July, the synoptic wind blows 
from the northwest over Toulouse (T), Lyon (L), and Marseille (M). The wind over Bordeaux (B) blows from the west, and turns to southeast during the day. The pollution plume from Bordeaux has a maximum aerosol mass concentration of $4 \mu \mathrm{g} \mathrm{m}^{-3}$, with the same order of magnitude as the plume from Lyon or Toulouse where the plume has a maximum concentration of 5 and $4 \mu \mathrm{g} \mathrm{m}^{-3}$ respectively. On the contrary, the plume from Marseille is mainly out of the boundaries of the domain because of the high wind regime blowing from land to sea $\left(>7 \mathrm{~m} \mathrm{~s}^{-1}\right)$. Figure $2 \mathrm{~b}$ shows that during the night between 3 and 4 July, the wind velocities stagnate, and especially over the Toulouse area. The plume emitted earlier from Bordeaux reaches the northwest of Toulouse during the night with concentrations of $5 \mu \mathrm{g} \mathrm{m}^{-3}$ as shown in Fig. $2 \mathrm{~b}$. The plume originating from Lyon reaches the Mediterranean Sea, $100 \mathrm{~km}$ east of Marseille. Then, during the day of 4 July the air flow reverses and the wind blows from southeast over Toulouse. The gas-phase precursors accumulated over Toulouse during the night are mixed with the plume from Bordeaux. In the simulation, the pollution plume emitted on 3 July from Bordeaux reaches an area situated $50 \mathrm{~km}$ to the northeast of Toulouse at 00:00 UTC on 4 July when the wind reverses (Fig. 2b). Figure 2c shows the fresh plume from Toulouse almost mixing with the plume emitted from Bordeaux the previous day. The advection of this resulting plume leads to a meeting with a local aerosol concentration maximum located over Bordeaux due to a very low wind regime $\left(<2 \mathrm{~m} \mathrm{~s}^{-1}\right)$ and the accumulation of particles. The evolution of aerosol mass concentrations as shown in Fig. 2 highlights the regional interactions between different cities. Indeed, the pollution plume developed during 4 July along an axis between Toulouse and Bordeaux appears to be a succession of three local maxima resulting from the fresh emissions from Toulouse, the mixing of aerosols emitted by Bordeaux the previous day with secondary aerosols resulting from gas-phase emissions by the Toulouse area, and the fresh emissions from Bordeaux respectively. It is also worth noting that in these simulations, the high concentrations located on the southern-most part of Fig. $2 \mathrm{~b}$ and c come from outside the boundary of the domains and result from the injection by the MOCAGE fields into the largest domain.

\subsubsection{Sub-regional scale plumes}

The situation observed during the IOP can be analysed by dividing the 2-day period into 3 different regimes over the Toulouse area. Figure 3 illustrates the different situations using model results from the second domain at the surface. During the first $18 \mathrm{~h}$, a moderate wind (more than $6 \mathrm{~m} \mathrm{~s}^{-1}$ ) blows from northwest over Toulouse. Figure 3a describes this situation at 10:00 UTC on 3 July. Primary aerosol concentrations (left) are concentrated over Toulouse (T) where they are emitted with a maximum of mass concentration of $4 \mu \mathrm{g} \mathrm{m}^{-3}$. Regional cities such as Agen (A), Castres (C), Carcassonne (CC) and Saint-Gaudens (SG) also exhibit lo- cal maxima of primary aerosols. The secondary aerosol particles are concentrated along the plume where the gas-phase precursors needed for the photo-reactions are located. The maximum of the secondary aerosols concentration is located $30 \mathrm{~km}$ southeast of Toulouse with a value of $6 \mu \mathrm{g} \mathrm{m}^{-3}$.

During the night a low-wind regime develops with mean wind velocities values about $2 \mathrm{~m} \mathrm{~s}^{-1}$ and a maximum of $4 \mathrm{~m} \mathrm{~s}^{-1}$. Moreover, on the northwestern-most section of the domain (point A, on Fig. 3b) one can observe a confluence of winds from the south, east and northwest. This phenomena leads to an accumulation of primary aerosols with concentrations higher than $5 \mu \mathrm{g} \mathrm{m}^{-3}$ located over Toulouse as shown on Fig. $3 b$ (left). The secondary aerosol concentrations (right) are quite high $\left(6 \mu \mathrm{g} \mathrm{m}^{-3}\right)$ on the southeast area of Toulouse (A) due to the resulting plume from Toulouse created on $3 \mathrm{July}$, and stopped $10 \mathrm{~km}$ west of CC during the night because of the low wind regime. The minimum value is below $1 \mu \mathrm{g} \mathrm{m}^{-3}$ and is located over the city of Toulouse. Finally, from 4 July, 06:00 UTC, (not shown here) to the end of the period, the wind reverses and blows from southeast with typical speed of $6 \mathrm{~m} \mathrm{~s}^{-1}$. As shown in Fig. 3c, on 4 July at 10:00 UTC, the primary aerosols are again concentrated over Toulouse, where they are emitted, with a maximum of $7 \mu \mathrm{g} \mathrm{m}^{-3}$. The secondary aerosol concentrations are high $\left(>7 \mu \mathrm{g} \mathrm{m}^{-3}\right)$ in the Toulouse plume due to the high concentrations of gas-phase precursors accumulated during the night. The other plume visible at point $\mathrm{A}$ and to the east results from the high concentration of gas-phase precursors such as $\mathrm{SO}_{2}, \mathrm{NH}_{3}$ and VOC transported from a plume emitted earlier from Bordeaux that accumulated during the night.

\subsection{Urban scale simulations analyses}

The model results at local scale have been evaluated in regard to observations. The dynamics and aerosol evolution are both compared to measurements.

\subsubsection{Evolution of the dynamics}

Figure 4 represents the modeled (a) and observed (b) evolution of the wind direction, and the modeled (c) and observed (d) wind speed during the $48 \mathrm{~h}$ of the simulation. Observations were carried out with an Ultra High Frequency (UHF) radar located in Toulouse downtown (Masson et al., 2008). Figure 4 allows us to focus on the different wind regimes observed over Toulouse and compare them with the simulation results. Figure $4 \mathrm{a}$ and $\mathrm{b}$ show that the wind direction on 3 July (plotted in light blue colors) is from northwest as described at the larger model domain (Sect. 2). On 4 July, the observations show a southeast wind (plotted in orange colors) within the mixing layer. The observations also show a wind shear with opposite directions above the boundary layer at $1000 \mathrm{~m}$ on 4 July 00:00 UTC and increasing to $2000 \mathrm{~m}$ between 12:00 to 18:00 UTC. The simulated wind regimes compare well with observation for the studied 


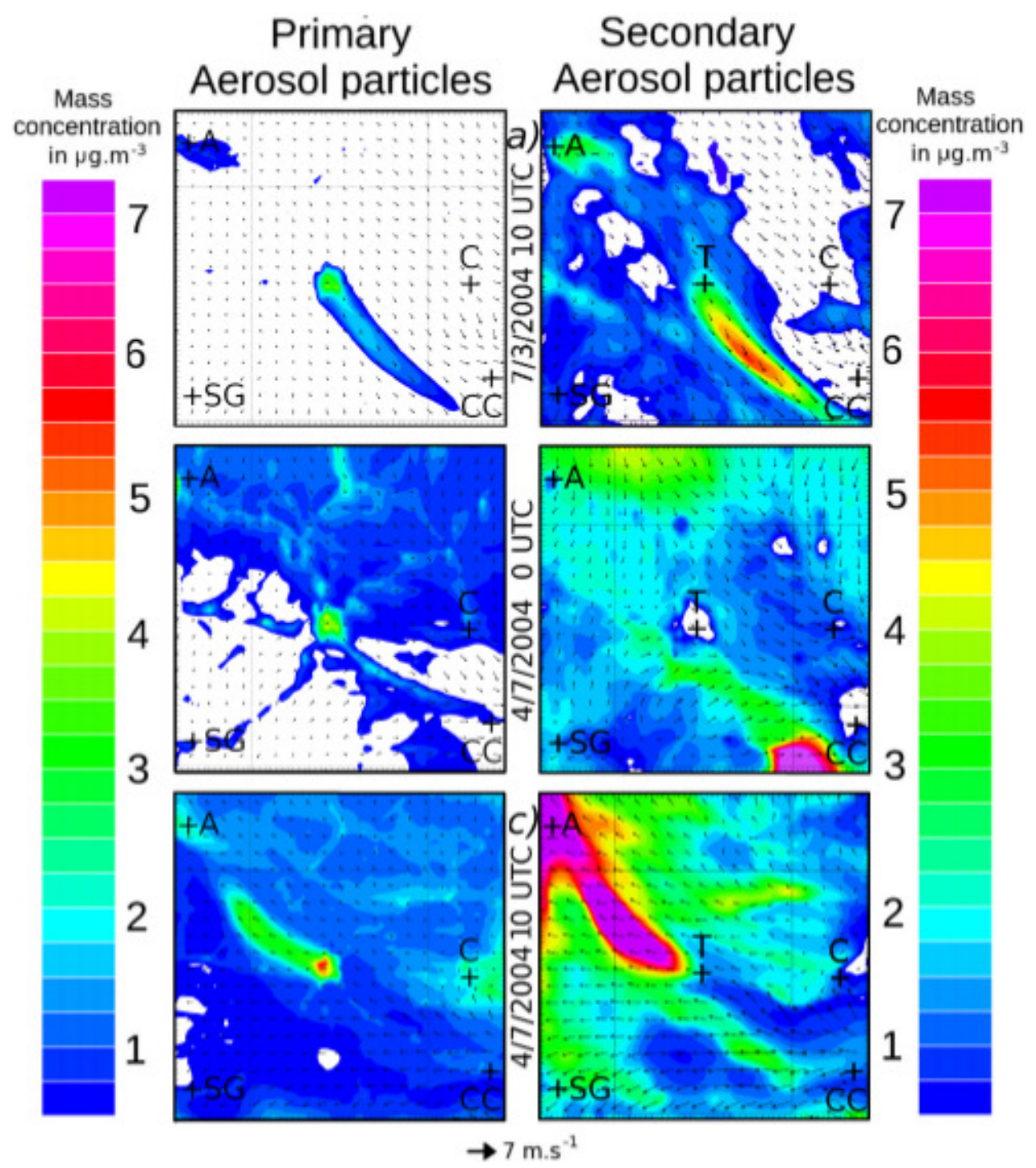

Fig. 3. Primary (left) and secondary (right) aerosol mass concentrations in $\mu \mathrm{g} \mathrm{m} \mathrm{m}^{-3}$ over the second domain (a) on 3 July 10:00 UTC, (b) on 4 July 00:00 UTC and (c) on 4 July 10:00 UTC with the wind vectors at the ground level (black arrows).Black crosses mark the location of regional cities: T for Toulouse, A for Agen, C for Castres, SG for Saint-Gaudens, and CC for Carcassonne.

period including the shear above the boundary layer itself and the boundary layer height which can be deduced from the altitude of the shear as well. However, there are still some differences between the observations and simulation results. First, during the night, the observed and modeled wind directions above the height of $1000 \mathrm{~m}$ are almost opposite. Second, the height of the shear during the night is not the same. From 00:00 to 06:00 UTC, the simulation represents a shear at $700 \mathrm{~m}$ height, while the observations show a shear at about $1000 \mathrm{~m}$ height.

Figure $4 \mathrm{c}$ and $\mathrm{d}$ show the modeled and observed evolution of wind velocity profiles. While the wind direction observations show relatively low noise, the wind velocities observed are more random. Nevertheless, the observations first show that the wind speed is around $5 \mathrm{~m} \mathrm{~s}^{-1}$ in the boundary layer on 3 July from 12:00 to 20:00 UTC, and around $6 \mathrm{~m} \mathrm{~s}^{-1}$ on 4 July. During the night, the observations show a lower wind regime $\left(<3 \mathrm{~m} \mathrm{~s}^{-1}\right)$ from 3 July, 22:00 UTC, to 4 July, 06:00 UTC. Model results show the same low wind regime during the night for layers thinner than $1000 \mathrm{~m}$. However, the simulation results show that on 4 July, the wind blows back to northwest earlier than observed for lower layers. Moreover, on 3 and 4 July, while the model simulates a wind speed with lower maxima and higher minima, the average is similar to the observations. The average wind speed modeled for 3 July from 06:00 to 20:00 UTC at the ground level is $4 \mathrm{~m} \mathrm{~s}^{-1}$, compared to $5 \mathrm{~m} \mathrm{~s}^{-1}$ for the observations. Similarly, for 4 July from 06:00 to 20:00 UTC, the average modeled wind speed at the ground is $5 \mathrm{~m} \mathrm{~s}^{-1}$, compared to $6 \mathrm{~m} \mathrm{~s}^{-1}$ for the observations. While the main trend seems to be correctly simulated, 

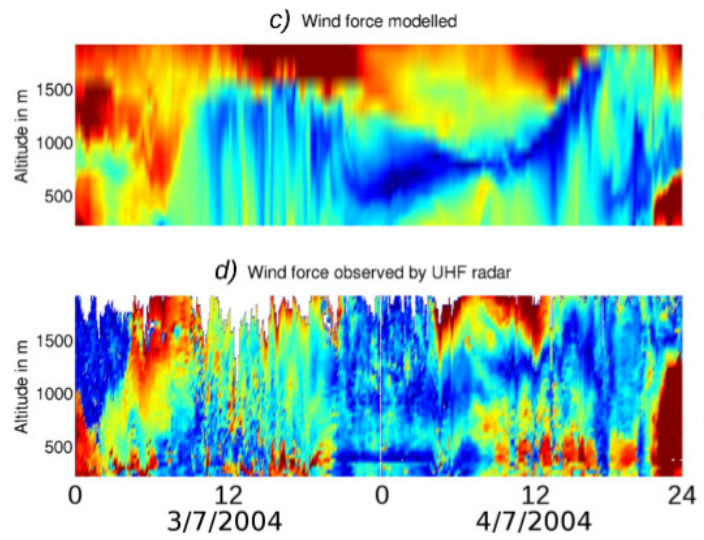

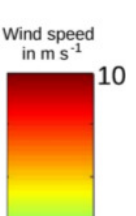

5

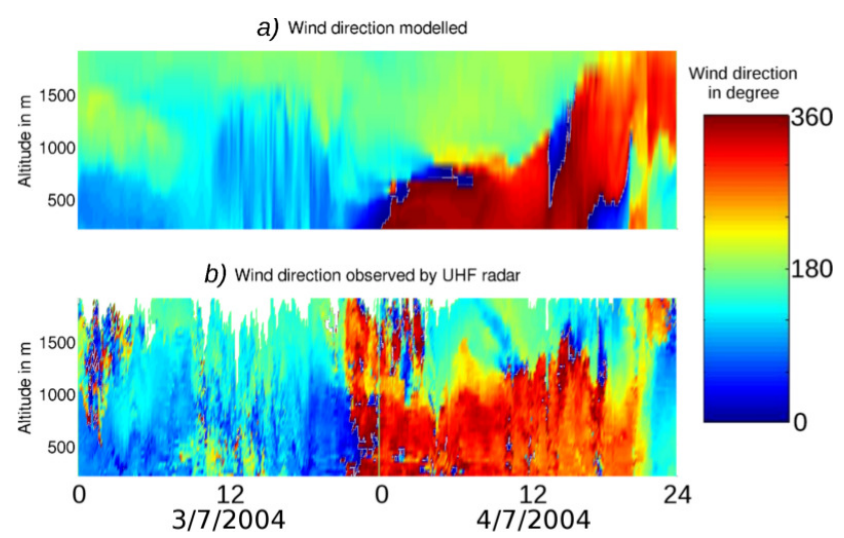

Fig. 4. Modeled and observed wind direction ( $\mathbf{a}$ and $\mathbf{b}$, respectively) and wind speed (c and $\mathbf{d}$, respectively). Observations carried out by an UHF radar.

the wind speed is slightly underestimated with respect to observations. In general, the model manages to reproduce the main trends for the win evolution (speed and direction). Most of the differences between observations and model results are below $1 \mathrm{~m} \mathrm{~s}^{-1}$ for the wind speed and 45 degrees for the direction.

Temperature and relative humidity observations from 21 meteorological stations in Toulouse area (black crosses on Fig. 1c) are compared with the model results. Figure 5a and $\mathrm{b}$ show the modeled and observed 2-m temperature and relative humidity at the location of the 21 light meteorological stations (black crosses in Fig. 1c). Figure $5 \mathrm{c}$ and d show the modeled and observed 2-m temperature and relative humidity at the location of the 4 main regional cities (Agen, Castres, Saint-Gaudens and Carcassonne). Figure $5 \mathrm{e}$ and $\mathrm{f}$ show the modeled and observed $10-\mathrm{m}$ zonal and meridian wind at the location of the same 4 main regional cities. The gray colour envelope encompasses all the observations during the 2-day IOP. The average value of the observations is drawn in black line. The minimum and maximum model values corresponding to the station's grid points are drawn in dashed blue line, and the model average value is drawn in cotinuous blue line.

Figure $5 \mathrm{a}$ and $\mathrm{b}$ show that the model manages to reproduce the 2-m temperature and relative humidity evolution during the 2-day IOP. The diurnal evolution of the parameters is correctly simulated as well as the minimum and maximum values. The main difference between the observations and the model results is for the maximum value of the temperature, which is underestimated by the model, and for which the model average value corresponds to the minimum observation value.

Figure $5 \mathrm{c}$ and $\mathrm{d}$ show that the diurnal evolution of the 2-m temperature and relative humidity at the four cities located all over the second domain is also correctly reproduced. Again, while the model also underestimates the maximum values of the temperature, the difference between the observations and the model results is higher than for Toulouse. This come from the fact that the domain resolution corresponding to the grid points is coarser. Therefore the precision of the physical processes solved is altered. It should also be noted that, whereas the spatial variability of the two parameters is higher on Fig. 5c and d than on Fig. 5a and b, the temporal evolution as well as the order of magnitude of the parameters remains the same.

Figure $5 \mathrm{e}$ and $\mathrm{f}$ show that the wind regimes observed at Toulouse (Fig. 4) also happens over the greater area corresponding to the second domain, and that this main trend is reproduced by the model. Indeed, during the first $18 \mathrm{~h}$, there is a northwest wind regime with a positive zonal wind values and a negative meridian wind values, then there is a low wind regime during the night, and finally a southeast wind regime for 4 July with negative zonal wind values and positive meridian wind values. Figure $5 \mathrm{e}$ and $\mathrm{f}$ also show that there is a higher variability of the wind observed values for the different cities, and that the model has difficulties to reproduce the same variability.

\subsubsection{Evolution of aerosol mass concentrations}

Another criteria of the model evaluation is to examine the modeled aerosol mass concentrations. Figure 6 shows the evolution of the measuremed (a) black carbon and (b) total aerosol mass concentrations (represented by black crosses) for the downtown site. Black carbon mass concentrations were measured by an aethalometer (model AE-30, Magee Scientific, USA) deriving the measured attenuation light beam by aerosols to absorption coefficient and then to black carbon concentrations. Total aerosol mass concentrations are the results of the merging of Scanning Mobility Particle Sizer (SMPS) particle measurements with a diameter between 15 to $600 \mathrm{~nm}$ and from an optical particle counter (OPC, model GRIMM 1.108) for the particles with a diameter between 

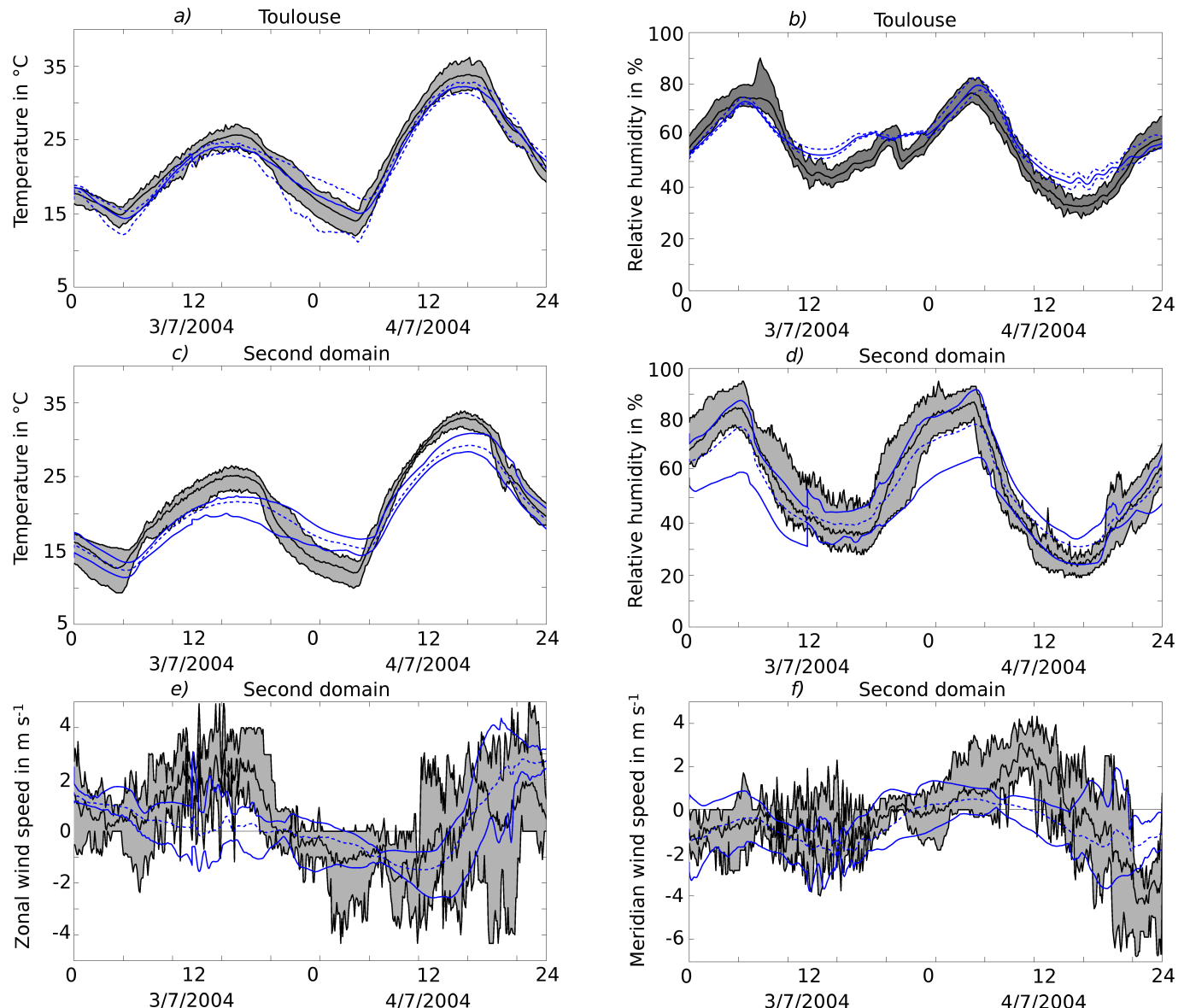

Fig. 5. (a) 2-m temperature in ${ }^{\circ} \mathrm{C}$ and (b) relative humidity in $\%$ observed by 21 stations located over Toulouse and modeled. (c) 2 -m temperature in ${ }^{\circ} \mathrm{C},(\mathbf{d})$ relative humidity in $\%$, (e) zonal and (f) meridian wind in $\mathrm{m} \mathrm{s}^{-1}$ observed by the meteorological stations located at the regional cities: Agen, Castres, Saint-Gaudens and Carcassonne. The envelope which encompass all the observed values are in gray area. The average value for observations is drawn in black line. The minimum and maximum modeled values are drawn in continuous blue line, and the average value is drawn in dashed blue line. All the model values result from the 500-m resolution domain computations.

0.3 to $20 \mu \mathrm{m}$. It also can be noted that the instruments were connected to a $\mathrm{PM}_{2.5}$ inlet. More information about the measurements are detailed by Gomes et al. (2008). The dashed blue lines show the evolution of the modeled black carbon, total aerosol, mass concentration over the third domain for the grid point of the downtown measurement site, and the blue plain lines denote the minimum and maximum of the modeled concentrations at grid points located in the downtown Toulouse stations which are all located over a 4 by $4 \mathrm{~km}$ square centered on the downtown-site. The average values corresponding to this area are drawn in dashed black line.

Both modeled black carbon and total aerosol mass concentrations have the same order of magnitude as the observations. It is noticeable that the temporal variability is high and even more pronounced for the black carbon mass concentrations. This can be explained by the direct link between black carbon concentrations and the traffic emissions. During the night between Saturday 3 July and Sunday 4 July, the observed and modeled black carbon concentrations increase, and this can be explained by an increase of traffic at 23:00 and 05:00 UTC on this week-end night, leading to emissions within a nocturnal boundary layer with a low height. However, the model seems to underestimate the total amount of aerosol mass concentrations during the afternoons with a bias of $4 \mu \mathrm{g} \mathrm{m}^{-3}$. Moreover the model results show high spatial variability as black carbon concentrations can reach $7 \mu \mathrm{g} \mathrm{m}^{-3}$ at 4 July 00:00 UTC at the downtown site, whereas some grid points in the 4 by $4 \mathrm{~km}$ area show concentrations below $1 \mu \mathrm{g} \mathrm{m}^{-3}$. Those temporal and spatial variabilities can also be noticed on the total mass concentrations with a maximum value of $60 \mu \mathrm{g} \mathrm{m}^{-3}$ and minimum value of $4 \mu \mathrm{g} \mathrm{m}^{-3}$.

The values modeled over the third domain for the grid point of the downtown measurement site can be compared with the values modeled over the second and the first domain which are drawn in dashed red, green lines, respectively. This comparison highlights that the evolution of total aerosol 

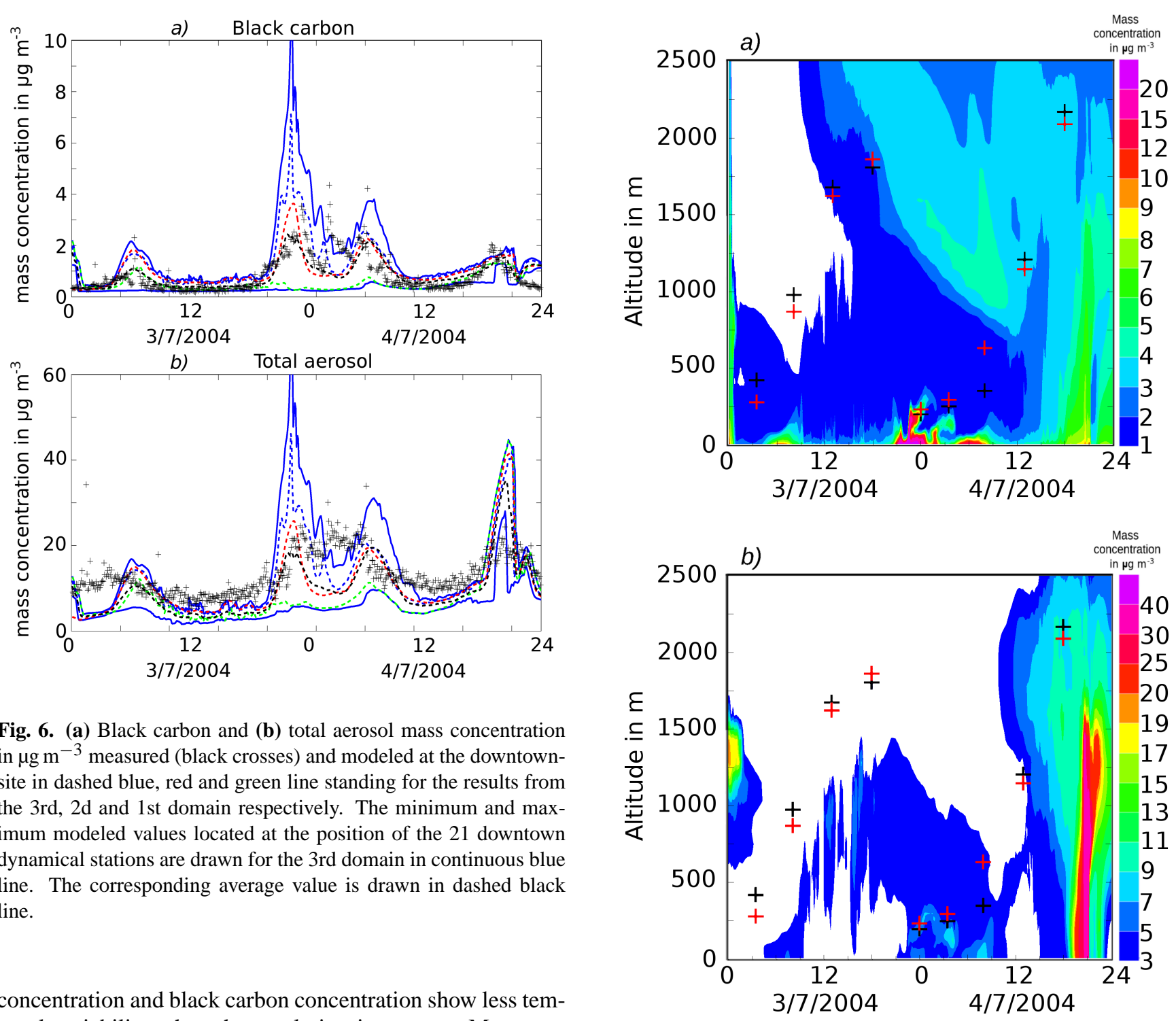

concentration and black carbon concentration show less temporal variability when the resolution is coarser. Moreover, the values modeled over the second domain are close to the average value over the third domain, which is consistent considering the $2.5 \mathrm{~km}$ grid size of the second domain and englobing $80 \%$ of the stations taken into account for the third domain. The comparison with the observations show that the model results are close to the observations, even if the temporal and spatial variability are less important. The values modeled over the first domain are close to the minimum value computed for the third domain comparison. Those values do not fit well with the observations, and are always below the observed values. This can be explained by the coarse resolution of $10 \mathrm{~km}$ which englobes the whole city of Toulouse as well as surrounding rural areas, which is therefore not able to reproduce the typical urban evolution of aerosol concentrations.

Figure 7 shows the evolution of (a) primary and (b) secondary aerosol mass concentration profiles over the downtown-site during the 2-day simulation. The boundary

Fig. 7. Primary (a) and secondary (b) aerosol mass concentration profiles modeled during the $48 \mathrm{~h}$ of simulation at the location of the downtown site grid point. The obsever (black crosses) and modeled (red crosses) boundary layer height are shown.

layer height observed by balloon measurements is overlaid with black crosses, and the height computed in the simulation is drawn with red crosses. Figure 7 confirms that the boundary layer height is well represented by the model. However, the height of the mixing boundary layer shows a consistent underestimation (with a difference between 50 and 200 meters), except on 4 July 08:00 UTC when simulations and observation show heights of $600 \mathrm{~m}$ and $300 \mathrm{~m}$, respectively. Figure 7 highlights the difference of vertical distributions between primary and secondary aerosols. Primary aerosols are mainly concentrated at the surface, whereas secondary aerosols vertical distribution is more chaotic. Figure 7 also 


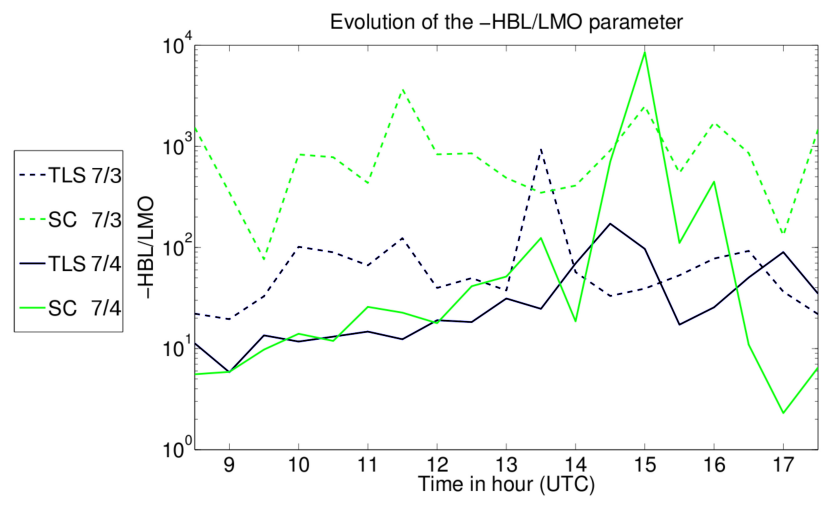

Fig. 8. Evolution of -HBL/LMO parameter observed over two sites: Toulouse downtown (TLS) and Saint-Sardos (SC) during the two days of the IOP

shows the temporal and vertical variability between primary and secondary aerosols, and illustrate that primary aerosol are concentrated when the emissions are the highest, i.e. when during episodes of high traffic: like on 4 July 00:00 UTC, when the observations show an emission peak of black carbon with a resulting maximum concentration of $4 \mu \mathrm{g} \mathrm{m}^{-3}$ (Fig. 6). Secondary aerosols mainly result from photochemistry which occurs with the solar radiation during the day. The highest concentrations of secondary aerosols over Toulouse occur from 06:00 to 20:00 UTC. On 4 July 02:00 UTC, the observations show a similar peak of black carbon resulting in a maximum of mass concentration of $4.5 \mu \mathrm{g} \mathrm{m}^{-3}$. While this peak is not represented by the simulation, we attribute this difference to observed and simulated meteorology; observations show a change in the wind field at 06:00 UTC (Fig. 4), while the model simulate this change at 02:00 UTC. Another peak of black carbon emission is on 4 July 06:00 UTC with a resulting maximum of Black Carbon mass concentration of $4.5 \mu \mathrm{g} \mathrm{m}^{-3}$. This peak is correctly represented by the model, and probably results from morning traffic linked with a low mixing layer, as shown with black and red crosses on Fig. 7.

We can also notice a mass of primary aerosols reaching Toulouse from 4 July at 10:00 UTC between 1200 and $200 \mathrm{~m}$. Finally, at the end of 4 July, a highly concentrated secondary aerosol air mass reaches Toulouse first $2000 \mathrm{~m}$ above the surface and followed by mixing throughout the column. The simulation shows that this air mass comes from the Mediterranean coast and is advected over Toulouse with high concentrations of nitrates.

\section{Development of the two different pollutants dispersion regimes}

While it is critical to know the dynamical situation for the understanding and forecasting of pollutant dispersion, it is natural to wonder if the model can reproduce complex situations such as convective rolls.

\subsection{Evolution of the dynamical parameter $-\frac{H_{\mathrm{BL}}}{L_{\mathrm{MO}}}$}

Observations such as the wind direction or the potential temperature illustrate that the dynamical situation over Toulouse is very different between the two days of simulation, as the potential temperature differs by $10 \mathrm{~K}$ between 3 and 4 July. To focus on those two different situations, Fig. 8 represents the evolution of the parameter $-\frac{H_{\mathrm{BL}}}{L_{\mathrm{MO}}}$, where $H_{\mathrm{BL}}$ is the boundary layer height and $L_{\mathrm{MO}}$ is the Monin-Obukhov length.

The Monin-Obukhov length is a characteristic length of the stability of the boundary layer, and is expressed as $L_{\mathrm{MO}}=\frac{u^{* 3} \theta \rho c_{p}}{\kappa g H}$ with $u^{*}$ the friction velocity, $\theta$ the potential temperature, $\rho$ the air density, $c_{\mathrm{p}}$ the air capacity, $\kappa$ the Von Karmann constant, $g$ the gravity acceleration, and $H$ the sensible heat flux.

The evolution of the parameter $-\frac{H_{\mathrm{BL}}}{L_{\mathrm{MO}}}$ is deduced from observations at two sites (Fig. 8: in black over the downtown site of Toulouse and in green over the Saint-Sardos site located $30 \mathrm{~km}$ northwest of Toulouse) and during the two days of the IOP (in continuous line for 3 July and in dashed line for the 4 July) Many experimental and modelling studies have characterised the behaviour of the boundary layer as a function of the parameter $-\frac{H_{\mathrm{BL}}}{L_{\mathrm{MO}}}$. Grossman (1982) describes the function of the parameter value as follows:

$--\frac{H_{\mathrm{BL}}}{L_{\mathrm{MO}}} \leq 5.0$ : only roll vortex motion

- $-\frac{H_{\mathrm{BL}}}{L_{\mathrm{MO}}} \leq 7.3$ : rolls coexist with convective cells and are necessary for their maintenance; rolls dominant

- 7.3 $\leq-\frac{H_{\mathrm{BL}}}{L_{\mathrm{MO}}} \leq 21.4$ : rolls coexist with convective cells but are not necessary for their maintenance; random cells dominant

- $21.4 \leq-\frac{H_{\mathrm{BL}}}{L_{\mathrm{MO}}}$ : random cells only but the shear is important to cell structure and morphology

Those values are deduced from the BOMEX campaign over the ocean. Other studies (Weckwerth, 1994; Moeng and Sullivan, 1994; Hartmann et al., 1997) suggested other criteria, but the trend is always the same with higher values of $-\frac{H_{\mathrm{BL}}}{L_{\mathrm{MO}}}$ representing conditions where convective cells dominate. Although most of these studies show the limits of $-\frac{H_{\mathrm{BL}}}{L_{\mathrm{MO}}}$ between 10 and 30 for the separation between cells and rolls, Christian and Wakimoto (1989) observed rolls over Colorado with a value of 270 for $-\frac{H_{\mathrm{BL}}}{L_{\mathrm{MO}}}$.

Thus, Fig. 8 shows that the dynamical structure over Toulouse area is different between the 2 days of simulation, 

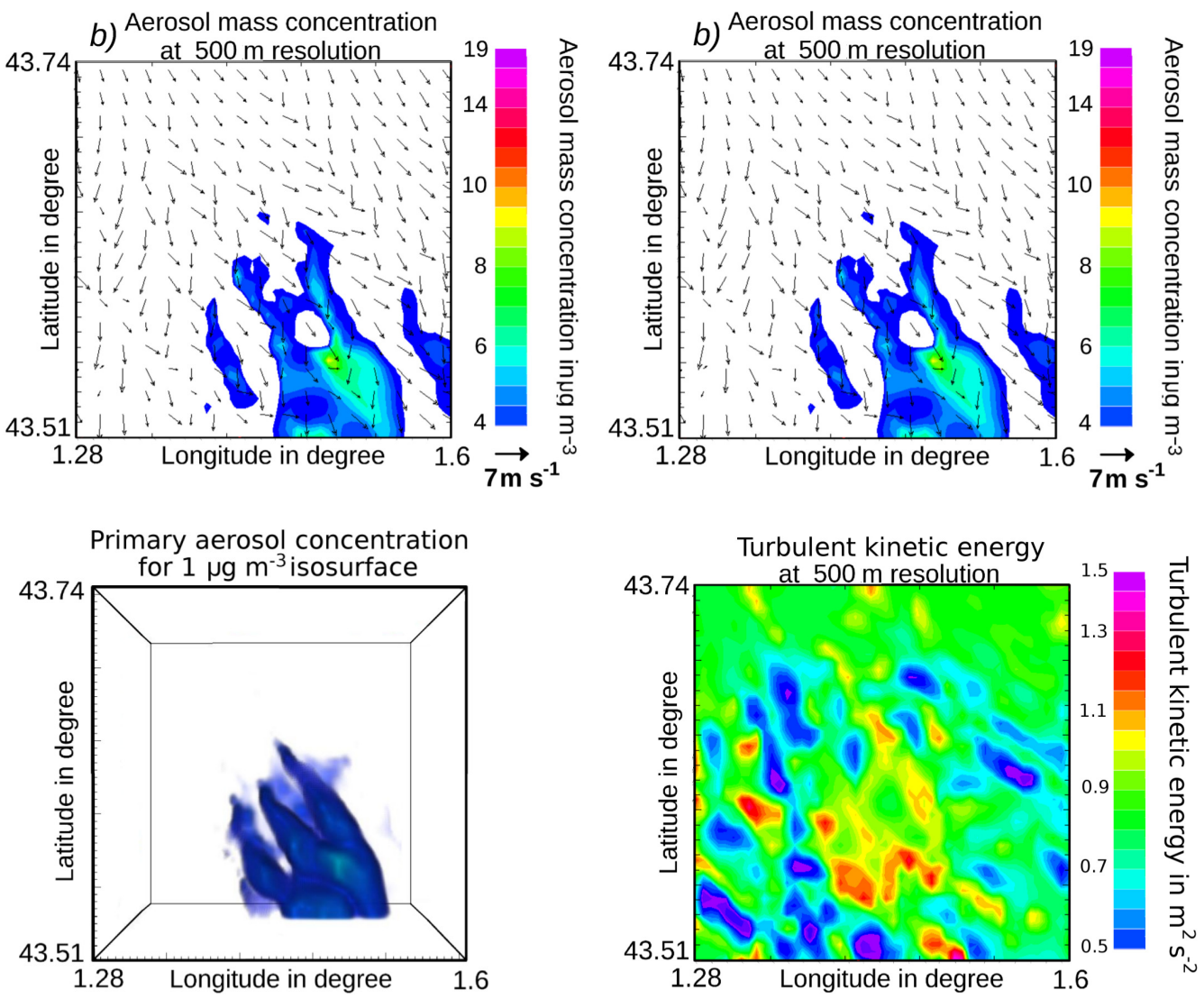

Fig. 9. (a) total aerosol mass concentration over the 2nd domain. (b) aerosol mass concentration over the 3rd domain. (c) 3-dimensional view of primary aerosol mass concentration for $1 \mu \mathrm{g} \mathrm{m}{ }^{-3}$ isosurface. (d) Turbulent kinetic energy over the 3rd domain. All results for 3 July at 12:00 UTC

and the parameter $-\frac{H_{\mathrm{BL}}}{L_{\mathrm{MO}}}$ shows values on 4 July lower than those on 3 July at the two observation sites. Moreover observations from the Toulouse site on 4 July (drawn in continuous black line) has values of $-\frac{H_{\mathrm{BL}}}{L_{\mathrm{MO}}}$ most often lower than 20 , which is a commonly observed value for the rolls. Therefore, we could expect the formation of rolls on 4 July.

As previously shown, the plume of particles is represented at the regional scale, by the formation of secondary aerosols in the plume of main cities such as Toulouse. However, with high resolution modelling, the distribution of aerosol particles shows a different shape. These differences are mainly due to effect of the resolution on the turbulent scheme used in the 2nd and 3rd domains. To understand the importance of turbulence regime for the particle dispersion, we focus on the dynamical conditions during the two days of the IOP.

\subsection{First day: classic plume of pollution with convective cells}

Figure 9 shows a set of 4 instantaneous fields at 12:00 UTC on 3 July. First, the horizontal cross section of the total aerosol mass concentration (i.e. the sum of primary and secondary particles) at $200 \mathrm{~m}$ a.g.l. over the $2 \mathrm{nd}$ domain is shown in Fig. 9a. The concentrations present a classic plume pattern, with a local maximum of $6 \mu \mathrm{g} \mathrm{m}^{-3}$ assumed to be primary aerosols as shown in Fig. 3 over the urban area of Toulouse, and $10 \mu \mathrm{g} \mathrm{m}^{-3}$ for aerosols, assumed to be secondary as shown in Fig. 3, $25 \mathrm{~km}$ southeast of Toulouse. The horizontal wind vectors are overlaid with black arrows.

Figure $9 \mathrm{~b}$ presents the same field over the 3rd domain. Unlike over the 2 nd domain, the concentrations seem to be concentrated along rolls. Those concentrations show a factor three in and out of the roll (from 4 to $12 \mu \mathrm{g} \mathrm{m}^{-3}$ ).

Figure $9 \mathrm{c}$ shows the volume of primary aerosol mass concentration equals to the $1 \mu \mathrm{g} \mathrm{m}^{-3}$ isocontour. While the horizontal cross section suggests that the aerosol concentrations are advected only along roll motion, the 3-D volume shows cell structures, which seem to concentrate a large amount of particles (eastern part of Fig. 9c).

Figure 9d shows the horizontal cross section of the turbulent kinetic energy in $\mathrm{m}^{2} \mathrm{~s}^{-2}$. Maximum values of turbulent kinetic energy are located over the city of Toulouse, and within the convective cells at the bottom of the domain with a value of $1.6 \mathrm{~m}^{2} \mathrm{~s}^{-2}$. Figure 9 illustrates results expected by 

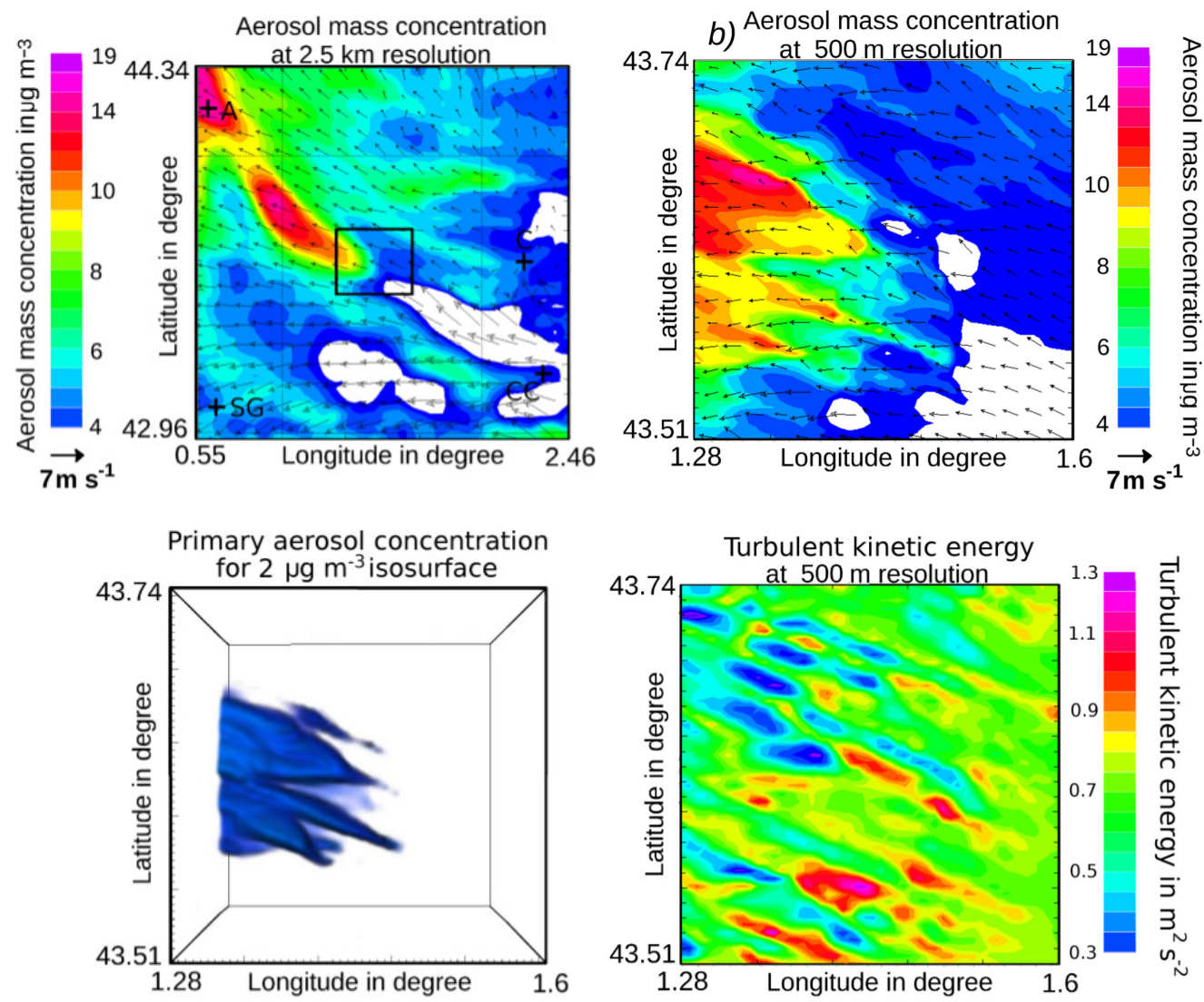

Fig. 10. (a) total aerosol mass concentration over the 2nd domain. (b) aerosol mass concentration over the 3rd domain. (c) 3-dimensional view of primary aerosol mass concentration for $2 \mu \mathrm{g} \mathrm{m} \mathrm{m}^{-3}$ isosurface. (d) Turbulent kinetic energy over the 3rd domain. All results for 4 July at 10:00 UTC

the observations of the parameter $-\frac{H_{\mathrm{BL}}}{L_{\mathrm{MO}}}$, i.e. coexisting cells and rolls. However, the model cannot reproduce those structures with a $2.5 \mathrm{~km}$ resolution. Only the 3rd domain with the $500 \mathrm{~m}$ resolution manages to reproduce this complex dynamical situation.

\subsection{Second day: turbulent rolls as pollutants drivers}

Figure 10 shows the same sets of the 4 instantaneous fields on 4 July at 12:00 UTC. Figure 10a also shows the horizontal cross section of the total aerosol mass concentration at 200 m a.g.l. over the 2nd domain (as in Fig. 10a). The concentrations still present a classic plume pattern with the concentration of aerosols, assumed to be secondary as shown in Fig. 3, higher than $12 \mu \mathrm{g} \mathrm{m}^{-3}$ located $25 \mathrm{~km}$ northwest of Toulouse. The horizontal wind vectors are overlaid with black arrows. Figure $10 \mathrm{~b}$ presents the same field over the 3 rd domain. The rolls are again modeled at 500-m resolution, and represent a more coherent structure. The difference between concentrations located in and out of the rolls is still higher than on 3 July, with values of $15 \mu \mathrm{g} \mathrm{m}^{-3}$ and $4 \mu \mathrm{g} \mathrm{m} \mathrm{m}^{-3}$ separated by only $3 \mathrm{~km}$.
Figure 10c shows that the volume of primary aerosol mass concentration equals to $2 \mu \mathrm{g} \mathrm{m}^{-3}$ and shows that aerosol particles are all concentrated within the rolls. The concentrations over the altitude of $1500 \mathrm{~m}$ are not shown in this 3-D volume. Unlike 3 July, there are no cells and the rolls show a coherent 3-dimensional structure.

Figure 10d shows the horizontal cross section of the turbulent kinetic energy in $\mathrm{m}^{2} \mathrm{~s}^{-2}$. There is a high spatial variability for the turbulent kinetic energy The main differences between 3 and 4 July are the values and the localisation of maximum and minimum of turbulent kinetic energy. The values of turbulent kinetic energy are lower on 4 July and show coherent roll structures. These rolls develop from the borders of the domain and concentrate a large amount of aerosol particles.

Figure 10 illustrates results expected by the observations of the parameter $-\frac{H_{\mathrm{BL}}}{L_{\mathrm{MO}}}$, i.e., only convective rolls are present. However, even when only rolls are present, the model still cannot reproduce those structures with a resolution of $2.5 \mathrm{~km}$. Only the $3 \mathrm{rd}$ domain with a resolution of 500 $\mathrm{m}$ manages to reproduce this complex dynamical situation. 


\section{Conclusions}

Having a better understanding of the urban meteorological processes is necessary to improve the air quality monitoring. In that context, measurements acquired during the CAPITOUL field experiment allowed us to evaluate the performance of high resolution numerical simulations, aiming at reproducing the dynamical situation, as well as the aerosol concentrations. One of the main sources of uncertainties in air quality forecasting results from representation of the meteorological conditions. Yet the meteorological fields strongly depend on the resolution of the domains. In this study, the importance of the horizontal resolution has been highlighted for an adequate representation of the meteorological fields, and the link between the domain resolution and the kind of pollution investigated. While the $10 \mathrm{~km}$ resolution domain allows us to focus on pollution events and interaction amongst cities on a regional scale, the 500-m resolution domain permits investigation of the role of boundary layer structure in determining the distribution of pollutant. Both dynamical and aerosol concentration fields were correctly reproduced by the simulation during the two-day IOP over Toulouse. The results of the 500-m resolution simulation showed that during these two days, the turbulent situation was different with convective rolls concentrating the major part of the aerosol particles. The impact of this roll structure is highlighted by the differences of pollutant concentrations, located over distances shorter than $3 \mathrm{~km}$, which can reach a factor of 5 . Consequently, this study illustrates the importance in reproducing such structures in case of local pollution event or chemical accident. The suggested high sensitivity of roll structures to dynamical situation should be further investigated; in particular, the feedbacks of aerosol particles on atmospheric dynamics through radiative forcing. Moreover, the sensibility of a 3 dimensional simulation at high resolution to EQSAM scheme should also be further estimated and compared with more accurate schemes.

Acknowledgements. The authors are indebted to Valery Masson for the organization of the CAPITOUL experiment. They gratefully thank Meteo France for its support. Logistic help from local agencies (La Poste, ORAMIP) is gratefully acknowledged. The authors would also like to thank G. Roberts for his valuable comments on this paper.

Edited by: N. Riemer

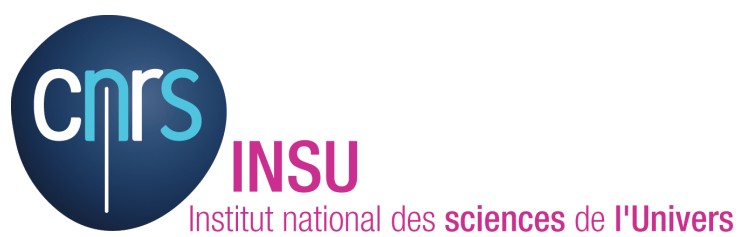

The publication of this article is financed by CNRS-INSU.

\section{References}

Aiken, A. C., de Foy, B., Wiedinmyer, C., DeCarlo, P., Ulbrich, I., Wehrli, M., Szidat, S., Prevot, A., Noda, J., Wacker, L., Volkamer, R., Fortner, E., Wang, J., Laskin, A., Shutthanandan, V., Zheng, J., Zhang, R., Paredes-Miranda, G., Arnott, W., Molina, L., Sosa, G., Querol, X., and Jimenez, J.: Mexico city aerosol analysis during MILAGRO using high resolution aerosol mass spectrometry at the urban supersite (T0) - Part 2: Analysis of the biomass burning contribution and the non-fossil carbon fraction, Atmos. Chem. Phys., 10, 5315-5341, doi:10.5194/acp-10-53152010, 2010.

Baklanov, A., Hnninen, O., Slørdal, L. H., Kukkonen, J., Bjergene, N., Fay, B., Finardi, S., Hoe, S. C., Jantunen, M., Karppinen, A., Rasmussen, A., Skouloudis, A., Sokhi, R. S., Sørensen, J. H., and Ødegaard, V.: Integrated systems for forecasting urban meteorology, air pollution and population exposure, Atmos. Chem. Phys., 7, 855-874, doi:10.5194/acp-7-855-2007, 2007.

Bessagnet, B., Menut, L., Curci, G., Hodzic, A., Guillaume, B., Liousse, C., Moukhtar, S., Pun, B., Seigneur, C., and Schulz, M.: Regional modeling of carbonaceous aerosols over Europe - Focus on Secondary Organic Aerosols, J. Atmos. Chem., in press, 2009.

Bougeault, P. and Lacarrere, P.: Parametrization of orographyinduced turbulence in a meso-beta model, Mon. Weather Rev., 117, 1872-1890, 1989.

Brown, L.: Eco-Economy: Building an Economy for the Earth, 2001.

Cachier, H., Aulagnier, F., Sarda, R., Gautier, F., Masclet, P., Besombes, J., Marchand, N., Despiau, S., Croci, D., Mallet, M. Laj, P., Marinoni, A., Deveau, P., Roger, J., Putaud, J., van Dingenen, R., Dell'Acqua, A., Viidanoja, J., dos Santos, M. M., Liousse, C., Cousin, F., Rosset, R., Gardrat, E., and Galy-Lacaux, C.: Aerosol studies during the ESCOMPTE Experiment: an overview, Atmos. Res., 74, 547-563, 2005.

Christian, T. and Wakimoto, R.: The relationship between radar reflectivities and clouds associated with horizontal roll convection on 8 August 1982, Mon. Weather Rev., 117, 1530-1544, 1989.

Cubison, M. J., Alfarra, M., Allan, J., Bower, K., Coe, H., McFiggans, G., Whitehead, J., Williams, P., Zhang, Q., Jimenez, J., Hopkins, J., and Lee, J.: The characterisation of pollution aerosol in a changing photochemical environment, Atmos. Chem. Phys., 6, 5573-5588, doi:10.5194/acp-6-5573-2006, 2006.

Fairall, C., Hare, J. E., Grachev, A. A., and Edson, J. B.: Bulk parameterization of air-sea fluxes: Updates and verification for the COARE algorithm., J. Climate, 16, 571-591, 2003.

Gomes, L., Mallet, M., Roger, J., and Dubuisson, P.: Effects of the physical and optical properties of urban aerosols measured during the CAPITOUL summer campaign on the local direct radiative forcing, Meteorol. Atmos. Phys., 108, 289-306, 2008.

Griffin, R., Dabdub, D., and Seinfeld, J.: Secondary organic aerosol. 1. Atmospheric chemical mechanism for production of molecular constituents, J. Geophys. Res., 107(D17), 4332, doi:10.1029/2001JD000541, 2002.

Gross, A., Amstrup, B., Baklanov, A., Lorenzen, T., and Sorensen, J. H.: CAC: An Air Pollution Model from Regional to Urban Scale Modellinge, CAC: An Air Pollution Model from Regional to Urban Scale Modelling, edited by: Baklanov, A., Mahura, A., and Sokhi, R., Copenhagen, 128-134, 2007.

Grossman, R.: An analysis of vertical velocity spectra obtained in 
the BOMEX fair-weather, trade-wind boundary layer, Bound.Lay. Meteorol., 23, 323-357, 1982.

Hartmann, J., Kottmeier, C., and Raasch, S.: Roll vortices and boundary layer development during a cold air outbreak, Bound.Lay. Meteorol., 84, 45-65, 1997.

Lafore, J. P., Stein, J., Asencio, N., Bougeault, P., Ducrocq, V., Duron, J., Fischer, C., Hreil, P., Mascart, P., Masson, V., Pinty, J. P., Redelsperger, J. L., Richard, E., and Vil-Guerau de Arellano, J.: The Meso-NH Atmospheric Simulation System. Part I: adiabatic formulation and control simulations, Ann. Geophys., 16, 90-109, doi:10.1007/s00585-997-0090-6, 1998.

Lefevre, F., Brasseur, G., Folkins, I., Smith, A., and Simon, P.: Chemistry of the 1991-1992 stratospheric winter: threedimensional model simulations, J. Geophys. Res., 99(D4), 81838195, 1994.

Masson, V.: A physically-based scheme for the urban energy balance in atmospheric models, Bound.-Lay. Meteorol., 94, 357397, 2000.

Masson, V., Gomes, L., Pigeon, G., Liousse, K., Lagouarde, J.P., Voogt, J., Salmond, J., Oke, T., Legain, D., Garrouste, O., and Tulet, P.: The Canopy and Aerosol Particles Interactions in TOulouse Urban Layer (CAPITOUL) experiment, Meteorol. Atmos. Phys., 102(3-4), 2008.

Matsui, H., Koike, M., Takegawa, N., Kondo, Y., Griffin, R. J., Miyazaki, Y., Yokouchi, Y., and Ohara, T.: Secondary organic aerosol formation in urban air: Temporal variations and possible contributions from unidentified hydrocarbons, J. Geophys. Res., 114, D04201, doi:10.1029/2008JD010164, 2009.

Metzger, S., Dentener, F., Pandis, S., and Lelieveld, J.: Gas/aerosol partitioning: 1. A computationally efficient model, J. Geophys. Res., 107, ACH16.1-ACH16.24, 2002.

Moeng, C. and Sullivan, P.: A comparison of shear and boyancy driven planetary boundary layer flows, J. Atmos. Sci., 51, 9991022, 1994.

Noilhan, J. and Planton, S.: A simple parameterization of land surface processes for meteorological models, Mon. Weaher Rev., 117, 536-549, 1989.
Ntziachristos, L., Gkatzoflias, D., Kouridis, C., and Samaras, Z.: COPERT: A European Road Transport Emission Inventory Model, Environmental Science and Engineering, Part 2, 491504, doi:10.1007/978-3-540-88351-7_37, 2009.

Salgado, R. and Moigne, P. L.: Coupling of the FLake model to the Surfex externalized surface model, Boreal Env. Res., 15, in press, 2010.

Smith, S. and Mueller, S. F.: Modeling natural emissions in the Community Multiscale Air Quality (CMAQ) Model - I: building an emissions data base, Atmos. Chem. Phys., 10, 4931-4952, doi:10.5194/acp-10-4931-2010, 2010.

Tulet, P., Crassier, V., Solmon, F., Guedalia, D., and Rosset, R.: Description of the MESOscale NonHydrostatic Chemistry model and application to a transboundary pollution episode between northern France and southern England, J. Geophys. Res., 108(D1), 4021, doi:10.1029/2000JD000301, 2003.

Tulet, P., Crassier, V., Cousin, F., Shure, K., and Rosset, R.: ORILAM, A three moment lognormal aerosol scheme for mesoscale atmospheric model. On-line coupling into the MesoNH-C model and validation on the ESCOMPTE campaign, J. Geophys. Res., 110, D18201, doi:10.1029/2004JD005716, 2005.

Tulet, P., Grini, A., Griffin, R., and Petitcol, S.: ORILAM-SOA: A computationally efficient model for predicting secondary organic aerosols in 3D atmospheric models, J. Geophys. Res., 111, doi:10.1029/2006JD007152, 2006.

Visschedijk, A., Zandveld, P., and van der Gon, H.: A High Resolution Gridded European Emission Database for the EU Integrated Project GEMS, Technical Report TNO, aR0233/B, TNO, Apeldoorn, 2007.

Weckwerth, T.: A study of horizontal convective rolls occuring within clear-air convective boundary layers, Thesis of University of California, Los Angeles, National Center for Atmospheric Research, 179 pp., 1994. 